\title{
Markers of healthy eating habits, water intake, and constipation in children between 4 and 7 years of age
}

\section{Marcadores de alimentação saudável, ingestão de água e constipação intestinal em crianças de 4 a 7 anos de idade}

\author{
Cristiana Santos ANDREOLI1 ${ }^{1}$ (D) 0000-0001-8765-3896 \\ Sarah Aparecida RIBEIRO-VIEIRA² (D) 0000-0002-0304-2711 \\ Poliana Cristina de Almeida FONSÊCA ${ }^{3}$ (D) 0000-0002-8875-5154 \\ Ana Vládia Bandeira MOREIRA 4 (ID) 0000-0001-6899-7378 \\ Sônia Machado Rocha RIBEIRO5 (iD) 0000-0002-9296-0011 \\ Sylvia do Carmo Castro FRANCESCHINI ${ }^{5}$ (D) 0000-0001-7934-4858
}

\section{A B S T R A C T}

\section{Objective}

To evaluate the association between diet and constipation in children between four and seven years of age.

1 Instituto Federal de Minas Gerais, Curso Superior de Tecnologia em Gastronomia. Campus Ouro Preto, R. Pandiá Calógeras, 898, Morro do Cruzeiro, 35400-000, Ouro Preto, MG, Brasil. Correspondência para/Correspondence to: CS ANDREOLI. E-mail: <cristiana.andreoli@ifmg.edu.br>.

2 Universidade Federal do Espírito Santo, Curso de Nutrição, Departamento de Educação Integrada em Saúde. Vitória, ES, Brasil.

${ }^{3}$ Universidade Federal do Universidade Federal do Maranhão, Curso de Nutrição, Departamento de Ciências Fisiológicas. São Luís, MA, Brasil.

4 Universidade Federal de Juiz de Fora, Curso de Nutrição, Departamento de Nutrição. Juiz de Fora, MG, Brasil.

${ }^{5}$ Universidade Federal de Viçosa, Departamento de Nutrição e Saúde, Programa de Pós-Graduação em Ciência da Nutrição. Viçosa, MG, Brasil.

Support: Fundação de Amparo à Pesquisa do Estado de Minas Gerais (02055-13).

Article based on the thesis of CS ANDREOLI, entitled "Hábitos alimentares, adiposidade corporal, estilo de vida e constipação intestinal em crianças de 4 a 7 anos de idade". Universidade Federal de Viçosa; 2018.

Como citar este artigo/How to cite this article

Andreoli CS, Ribeiro-Vieira SA, Fonseca PCA, Moreira AVB, Ribeiro SMR, Franceschini SCC. Markers of healthy eating habits, water intake, and constipation in children between 4 and 7 years of age. Rev Nutr. 2018;31(4):363-72. http:// dx.doi.org/10.1590/1678-98652018000400002 


\section{Methods}

A cross-sectional study with 152 children between 4 and 7 years of age residing in Viçosa, Brazil. Constipation was defined in accordance with the Rome IV diagnostic criteria. Dietary habits were evaluated based on the frequency of food intake using a food diary for three days. Dietary analysis considered foods deemed healthy and unhealthy which could be associated with constipation, as well as the children's consumption of fruits and vegetables. The amounts of fiber and water consumed were also rated as adequate or inadequate. As part of the analyses, Student's $t$-test and the chi-square test were performed with a significance level of $p<0.05$.

\section{Results}

The prevalence of constipation was $32.2 \%$. Constipation was more common among children who did not consume fruits $(p=0.020)$ or greens $(p=0.002)$, as well as among children who consumed "instant" chocolate drinks ( $p=0.033)$. An association was found between the frequent consumption of fried food $(p=0.020)$, a daily water intake lower than $600 \mathrm{~mL}$, and constipation $(p=0.028)$.

\section{Conclusion}

Unhealthy eating habits among children, such as the lack of fruit and greens intake and the consumption of "instant" chocolate drinks and fried foods, were found to be positively correlated with constipation. The low fruit and vegetable consumption observed herein reflects the need for changes in children's eating habits and the implementation of measures to promote the intake of healthy foods.

Keywords: Child. Constipation. Feeding behaviour. Food Consumption.

\section{R E S U M O}

\section{Objetivo}

O estudo visa avaliar a associação do consumo alimentar de crianças de quatro a sete anos de idade com constipação intestinal.

\section{Métodos}

Foi realizado estudo transversal com 152 crianças de 4 a 7 anos, residentes em Viçosa, Minas Gerais, Brasil. A constipação intestinal foi identificada de acordo com os critérios de Roma IV. Avaliou-se o consumo alimentar por meio da frequência de consumo de alimentos e do registro alimentar de três dias. Na análise do consumo alimentar selecionaram-se os alimentos marcadores de alimentação saudável e não saudável que poderiam estar associados à constipação, além do consumo agrupado de frutas, verduras e legumes. Verificou-se ainda adequação do consumo de fibras e ingestão de água. Nas análises, foram realizados os testes t-Student e quiquadrado, considerando-se como significância estatística $p<0,05$.

\section{Resultados}

A prevalência de constipação foi de $32,2 \%$, sendo maior entre as crianças que não consumiam frutas $(p=0,020)$ e verduras $(p=0,002)$ e consumiam achocolatados $(p=0,033)$. Houve associação entre a constipação $(p=0,028)$ e o consumo frequente de frituras $(p=0,020)$, ingestão diária de água inferior a $600 \mathrm{~mL}$.

\section{Conclusão}

Hábitos não saudáveis das crianças, como a baixa ingestão de frutas e verduras, e o consumo de achocolatado e frituras, contribuíram para a associação positiva com a constipação. O baixo consumo de frutas, verduras e legumes revela a necessidade de alteração dos hábitos alimentares das crianças, bem como da implantação de ações para incentivo ao consumo de alimentos saudáveis.

Palavras-chave: Criança. Constipação intestinal. Comportamento alimentar. Consumo de alimentos.

\section{NTRODUCTIO N}

Functional intestinal constipation is a common childhood health problem that affects the quality of life of children and families. The worldwide prevalence of functional constipation has been increasing, being widely variable according to the country $[1,2]$. In the studies performed with children in Brazil, the prevalence of constipation presented a wide variation, from $14.7 \%$ to $38.8 \%$ [3]. 
Currently, changes in dietary patterns, coupled with an increased consumption of ultraprocessed foods and a low consumption of highfiber foods [4], mainly fruits and vegetables, have contributed to an increase in overweight children [5], to an emergence of chronic diseases $[4,6]$ and for the development of functional disorders of the gastrointestinal tract $[5,7]$.

Studies evaluating the dietary intake of children with constipation generally assess the intake of macronutrients and fibers [810]. It is already known that fiber and water consumption help prevent constipation in adults $[11,12]$, however, there have been few studies that evaluate water intake $[8,13]$ in children and indefinite results regarding fibers $[14,15]$.

Considering the importance of healthy eating habits in childhood for the prevention of chronic noncommunicable diseases in adult life, the objective of this study was to evaluate the association between the dietary habits of children between four and seven years of age and intestinal constipation.

\section{METHODS}

It is a cross-sectional study with children who are part of a retrospective cohort of birth in the city of Viçosa, in the state of Minas Gerais, Brazil. The children were followed up through the Programa de Apoio à Lactação (PROLAC, Lactation Support Program) in the first year of life and reassessed between the ages of 4 to 7 years. PROLAC is an Extension program of the Universidade Federal de Viçosa (UFV, Federal University of Viçosa) [16].

Data collection was done in the years 2015 and 2016 in the University Division of Health, by previously trained post-graduate and undergraduate students of Nutrition.

Children were recruited based on the selection of PROLAC care records, according to the following criteria: presence of identification data that allowed to determine both the location of children and their birth dates, who should be between four and seven years-old at the time of the study. Children with endocrine, neurological and intestinal abnormalities were not included in the study.

Of the 298 children eligible to participate in the study, 98 children were not located (due to change of domicile) after at least three attempts at home visits; 47 did not complete all stages of the study or were not authorized by their parents; 1 of the children passed away during the development of this study. Thus, the study population consisted of 152 children.

Food-frequency lists and three-day dietary records were used to evaluate food consumption. The three-day dietary records were handed to the children responsible for filling them in, and they were instructed to do so on alternate days, with the inclusion of a weekend day. All records were checked and reviewed by the researchers, along with the parents or guardians.

The average energy consumption (Kcal/ day) and fiber intake in grams/day, referring to the three days of registration, was determined using the Dietpro software v5i (AS Systems, Viçosa, Brazil). The consumption of food in grams or milliliters was expressed based on a diet of 1000 calories per day aiming to adjust consumption according to the total energy intake in the diet [17].

To evaluate the consumption of ultraprocessed foods, the NOVA classification [18] was considered, and the percentage of caloric contribution was calculated in relation to the Total Energy Value (TEV) of the diet.

Adequacy of fiber intake was calculated based on the international dietary recommendations, which consider the following formula as the minimum fiber intake per day: the age of the child (years) plus $5 \mathrm{~g}$ [age $+5 \mathrm{~g} /$ day] [19].

The food frequency list consisted of ten foods or preparations: fruits, greens, vegetables, milk, legumes (beans), treats (candies, chewing 
gum, ready-made sweets), soft drinks or artificial juice, fried foods, sausages (hot dog, sausage and ham) and chocolate milk. The frequency of consumption was related to habitual consumption (last month) and the responses for each food item were: number of times consumed in the/per week, in the month, rarely and not consumed. The first five foods were considered markers of healthy eating habits, and the last five were considered as markers of unhealthy eating habits. In this study, the consumption of a given food at least four days of the week was considered as frequent consumption, as proposed by Alves et al. [20].

In addition, the consumption of the fruitsand-vegetables group, obtained by the sum of the daily intake (in grams), as recommended by the World Health Organization (WHO), was considered as the average of the three days and no tubers were included [6]. The consumption of the fruits-and-vegetables group was presented according to the $75^{\text {th }}$ percentile of each individual food and group.

Regarding the child's water intake, the usual water intake $(\mathrm{mL}) /$ day was investigated, considering a $200 \mathrm{~mL}$ glass as a standard measure [14].

Constipation was identified according to the criteria of Rome IV [21]. In addition, the Bristol Scale was used to check stool consistency. The scale classifies stool into seven categories ranging from hard $(1,2)$, normal $(3,4,5)$ and soft $(6,7)$ stool $[22,23]$.

In the statistical analysis, the normality of the variables was evaluated by the shapiro wilk test. The Student's t-test was used to compare the mean energy intake (Kcal/day) and the fiber intake (grams/day). The chi-square test was applied to compare the markers of eating habits, fruits-and-vegetables group and fiber adequacy between the two constipation groups. Statistical analyzes were performed in the Stata 13.0 software (Stata Corporation, College Station, Texas, United States), considering a statistical significance of $p<0.05$.
Parents or guardians read and signed the informed consent form for participation in the research. This research was approved by the Human Research Ethics Committee of the UFV (892.476/2014).

\section{RE S U L T S}

Of the 152 children evaluated, $54.6 \%$ $(n=83)$ were males, with mean age of 5.9 years (Standard Deviation [SD] 0.95). The Total Energy Value (TEV) was $1470.5 \mathrm{Kcal} /$ day for the group with constipation and $1508.7 \mathrm{Kcal} /$ day for the group without constipation, with ultraprocessed foods being responsible for $37.9 \%$ and $34.6 \%$, respectively, in the eating habits, without differences between both groups $(p=0.171)$. Regarding the adequacy of fiber intake, $69.0 \%$ of the children met the daily dietary recommendation of fiber intake $5 \mathrm{~g}$ [age $+5 \mathrm{~g} /$ day], and no difference was observed in adequacy between children with and without constipation ( $p=0.3319$ ).

When observing the prevalence of constipation among children according and the consumption of foods considered as markers of healthy eating habits (Table 1), there was a high prevalence of constipation among children who did not consume fruit $(p=0.020)$ and vegetables $(p=0.002)$. Although not statistically significant, the prevalence of constipation among children who did not consume vegetables (50.0\%) and legumes (66.7\%) was also high.

Regarding the consumption of prevalence of foods considered as markers of unhealthy eating habits, it was observed that the prevalence of constipation among children who consume treats $(53.8 \%)$, soft drinks (41.7\%), fried foods (33.1\%) and chocolate milk (34.7\%) was elevated, however, only the consumption of chocolate milk was associated with constipation $(p=0.033)$. We also identified that 55\% $(n=27)$ of the children who consumed chocolate milk daily (7 days/week) had constipation. 
Table 1. Prevalence of intestinal constipation according to the consumption of food considered as markers in children between 4 and 7 years-old. Viçosa (MG), Brazil, 2015-2016.

\begin{tabular}{llcl}
\hline \multirow{2}{*}{ Markers } & \multicolumn{2}{c}{ Consumption/intake } & \multirow{2}{*}{$p^{*}$} \\
\cline { 2 - 3 } Healthy & Yes (\%) & No (\%) & 0.020 \\
Fruits & 30.6 & 80.0 & 0.002 \\
Greens & 28.1 & 64.7 & 0.220 \\
Vegetables & 31.2 & 50.0 & 0.198 \\
Legumes & 31.5 & 66.7 & 0.754 \\
Milk & 32.4 & 25.0 & 0.081 \\
Unhealthy & & & 0.466 \\
Treats & 53.8 & 30.2 & 0.635 \\
Soft drinks & 41.7 & 31.4 & 0.924 \\
Fried food & 33.1 & 20.0 & 0.033 \\
Sausages & 32.2 & 33.3 & 0 \\
Chocolate milk & 34.7 & & \\
\hline
\end{tabular}

Note: ${ }^{*}$ Chi-square test.

Constipation was identified in $32.2 \%$ $(n=49)$ of the children, and $60.0 \%$ of children who did not eat fruits had stool types 1 and 2 $(p=0.017)$, according to the Bristol stool scale.

Table 2 shows the distribution of the frequent consumption of healthy and unhealthy food markers among the evaluated children. When analyzing food considered as markers of healthy eating habits, we highlight the high proportion of children with constipation who consumed fruits (47\%) and vegetables (51\%) less frequently.

In relation to the frequent consumption of unhealthy foods, it was observed that there was an association between the consumption of fried foods $(p=0.020)$, chocolate milk $(p=0.049)$ and constipation $(p=0.020)$. Expressive proportions of children with constipation who frequently consumed treats (30.6\%), soft drinks/ industrialized juices (38.8\%), and chocolate milk (67.0\%) were identified.

It was verified that $3.5 \%$ of children did not consume anything of the fruits-andvegetables group during the three days and more than $70.0 \%$ of the children presented some fruits-and-vegetables group consumption $<200 \mathrm{~g} /$ day, way below the daily dietary recommendations (Table 3).

In relation to water intake, the mean water intake ( $\mathrm{mL} /$ day) was higher than 3 cups $(600 \mathrm{~mL})$, and daily intake levels which were lower than $600 \mathrm{~mL}$ were associated with constipation $(p=0.028)$.

\section{DISCUSSION}

The results showed that the prevalence of constipation was higher among children who did not consume fruits and greens and consumed chocolate milk. In addition, the frequent consumption of foods considered as markers of unhealthy eating habits was high, especially in children with constipation, demonstrating the importance of evaluating markers of healthy and unhealthy eating habits in the etiopathogenesis of constipation in childhood.

In the study by Lee etal. [10], who evaluated the prevalence of constipation among preschool children, it was observed that the mean fruit consumption and the fruit, vegetable and cereal 
Table 2. Consumption of food considered as markers according to the presence of intestinal constipation in children between 4 and 7 years-old. Viçosa (MG), Brazil, 2015-2016.

\begin{tabular}{|c|c|c|c|c|c|}
\hline \multirow{3}{*}{ Markers } & \multicolumn{4}{|c|}{ Intestinal constipation } & \multirow{3}{*}{$p^{*}$} \\
\hline & \multicolumn{2}{|c|}{ Yes $(n=49)$} & \multicolumn{2}{|c|}{ No $(n=103)$} & \\
\hline & $\mathrm{n}$ & $\%$ & $n$ & $\%$ & \\
\hline \multicolumn{6}{|c|}{ Healthy } \\
\hline \multicolumn{6}{|l|}{ Fruits } \\
\hline$<4$ & 23 & 47.0 & 35 & 34.0 & 0.124 \\
\hline$\geq 4$ & 26 & 53.0 & 68 & 66.0 & \\
\hline \multicolumn{6}{|l|}{ Greens } \\
\hline$<4$ & 25 & 51.0 & 49 & 47.5 & 0.691 \\
\hline$\geq 4$ & 24 & 49.0 & 54 & 52.5 & \\
\hline \multicolumn{6}{|c|}{ Vegetables } \\
\hline$<4$ & 19 & 38.8 & 42 & 40.8 & 0.814 \\
\hline$\geq 4$ & 30 & 61.2 & 61 & 59.2 & \\
\hline \multicolumn{6}{|l|}{ Milk } \\
\hline$<4$ & 07 & 14.3 & 12 & 11.6 & 0.646 \\
\hline$\geq 4$ & 42 & 85.7 & 91 & 88.4 & \\
\hline \multicolumn{6}{|l|}{ Legumes } \\
\hline$<4$ & 4 & 8.2 & 8 & 7.8 & 0.933 \\
\hline$\geq 4$ & 45 & 91.8 & 95 & 92.2 & \\
\hline \multicolumn{6}{|c|}{ Unhealthy } \\
\hline \multicolumn{6}{|l|}{ Treats } \\
\hline$<4$ & 34 & 69.4 & 74 & 71.8 & 0.755 \\
\hline$\geq 4$ & 15 & 30.6 & 29 & 28.2 & \\
\hline \multicolumn{6}{|c|}{ Soft drinks } \\
\hline$<4$ & 30 & 61.2 & 64 & 62.7 & 0.857 \\
\hline$\geq 4$ & 19 & 38.8 & 38 & 37.3 & \\
\hline \multicolumn{6}{|c|}{ Fried food } \\
\hline$<4$ & 45 & 91.8 & 102 & 99.0 & 0.020 \\
\hline$\geq 4$ & 4 & 8.2 & 01 & 1.0 & \\
\hline \multicolumn{6}{|l|}{ Sausages } \\
\hline$<4$ & 44 & 89.8 & 99 & 96.1 & 0.123 \\
\hline$\geq 4$ & 5 & 10.2 & 4 & 3.9 & \\
\hline \multicolumn{6}{|c|}{ Chocolate milk } \\
\hline$<4$ & 16 & 32.6 & 51 & 49.5 & 0.049 \\
\hline$\geq 4$ & 33 & 67.4 & 52 & 50.5 & \\
\hline
\end{tabular}

Note: * ${ }^{*}$ hi-square test. Frequent ( $\geq 4$ days/week); less frequent $(<4$ days/week).

group showed lower levels in the group of children with constipation. A population-based study with 7 to 12 year-old children in Taiwan [2] identified a higher prevalence of constipation in children who consumed vegetables and fruits less frequently.

In the present study, the consumption of the fruits-and-vegetables group was low 
Table 3. Consumption of fruits, greens and vegetables in children between 4 and 7 years-old, according to the presence of intestinal constipation. Viçosa (MG), Brazil, 2015-2016.

\begin{tabular}{|c|c|c|c|c|c|}
\hline \multirow{3}{*}{ Markers } & \multicolumn{4}{|c|}{ Constipation } & \multirow{3}{*}{$p^{*}$} \\
\hline & \multicolumn{2}{|c|}{ Yes $(n=45)$} & \multicolumn{2}{|c|}{ No $(n=100)$} & \\
\hline & $n$ & $(\%)$ & $n$ & $(\%)$ & \\
\hline \multicolumn{6}{|l|}{ Fruits } \\
\hline$<p 75^{* *}$ & 33 & 73.3 & 72 & 72.0 & 0.868 \\
\hline$\geq p 75$ & 12 & 26.7 & 28 & 28.0 & \\
\hline \multicolumn{6}{|l|}{ Greens } \\
\hline$<\mathrm{p} 75$ & 35 & 77.8 & 77 & 77.0 & 0.918 \\
\hline$\geq p 75$ & 10 & 22.2 & 23 & 23.0 & \\
\hline \multicolumn{6}{|c|}{ Vegetables } \\
\hline$<\mathrm{p} 75$ & 35 & 77.8 & 73 & 73.0 & 0.542 \\
\hline$\geq p 75$ & 10 & 22.2 & 27 & 27.0 & \\
\hline \multicolumn{6}{|c|}{ Fruits-and-vegetables group } \\
\hline$<\mathrm{p} 75$ & 33 & 73.3 & 75 & 75.0 & 0.831 \\
\hline$\geq \mathrm{p} 75$ & 12 & 26.7 & 25 & 25.0 & \\
\hline
\end{tabular}

Note: *Chi-square test; Maximum percentage of unknown observations ( $n=8 ; 5,5 \%)$. " ${ }^{* *} 75$ : percentile75; p75 fruits (100g/day); p75 greens (15g/day); p75 vegetables (70g/day); p75 fruits-and-vegetables group (less than<200g).

( $<200 \mathrm{~g} /$ day), and $76 \%$ of the children consumed less than half of the daily fruits-and-vegetables group recommendation (>400g/day) [6]. These findings demonstrate that the eating habits of children in this age group is an issue to be studied, regardless of any associations with constipation.

Insufficient consumption of the fruitsand-vegetables group is among the top 10 risk factors for the global incidence of diseases [6]. The high prevalence of a less frequent healthy food intake observed in this study among children with constipation is concerning, especially in relation to fruits and vegetables, which are fundamental components of a healthy diet, since they contain micronutrients, fibers and functional components. According to the WHO [6], the consumption of foods from the fruits-and-vegetables group can help prevent chronic diseases in addition to protecting the gastrointestinal tract.

Asakura et al. [9] in a study with children carried out in Japan, when analyzing the local diet, found that the increase of fiber through the intake of fruits and vegetables was associated with a lower prevalence of constipation. The role of fibers in the prevention and treatment of constipation is frequently discussed in several studies with adults $[10,11]$, however, there is no established consensus regarding fiber intake and constipation in children, probably due to different study methodologies (the use of different food tables and dietary fiber recommendations that the ones used in the study), leading to controversial results $[9,10]$. In Brazil [24], in a study with children, the authors found that the diet of children with constipation had a lower amount of fiber, due to a lower frequency of the presence of fruits and fruit juice in the diet.

According to data from the Family Budget Survey 2008-2009 [25], Brazilians are replacing the consumption of healthy foods with high-energy and ready-to-eat, industrialized food. The consumption of ultra-processed foods compromises fiber intake, and the ingestion of these foods is directly associated with inadequate eating habits, contributing to overweight and constipation 
$[5,7]$. In addition, the high contribution of ultra-processed foods in the eating habits of children is highlighted, regardless of the presence of constipation, evidencing a poor quality of food in terms of food and nutrients representing a health risk [26].

In the present study, it was found that frequent consumption of unhealthy food considered as markers of unhealthy eating habits was high among children with constipation. However, it is noted that only the consumption of fried foods and chocolate milk was associated with constipation. In the study conducted in India by Sujatha et al. [27], it was observed in children that a higher consumption of junk food (fried food) was associated with the presence of constipation.

Corroborating these results, Shau et al. [7] and Olaru et al. [28] found that the frequent consumption of fast food and inadequate eating habits are associated with constipation [27]. Other authors $[7,28,29]$ suggest that the consumption of foods with high sugar, trans fat, sodium levels, and the inadequate intake of fruits and vegetables favor the increase in prevalence.

Regarding water intake, it is noteworthy that its association with constipation in children is still controversial $[2,14]$, partially because some studies consider the intake of liquids (water and other liquids) $[10,15]$, rather to analyze them separately $[13,14]$ which compromises the comparison of the results, and most importantly due to the small number of studies [30] performed, therefore, multicentric studies are needed to clarify this information.

One limitation of this study was the evaluation of food consumption through a dietary record and a list of food frequency, instruments that involve a possible bias of the individual's usual eating habits, due to memory failure of the interviewee, which may lead to over or underestimation of consumption [31].
In addition, it was not possible to evaluate all three-day records, as predicted, because of the difficulties of returning these by the mothers. And although the frequency list has not been validated, the way it was elaborated allowed to identify the intake of food considered as markers of healthy and unhealthy eating habits [32] and may better represent the habitual food intake [33].

\section{CONCLUSION}

This is the first study to verify the positive association of markers of healthy and unhealthy eating habits with constipation in children. Unhealthy habits such as not consuming fruits, greens, the consumption of chocolate milk and fried foods frequently contributed to the association with constipation. Evaluation through markers of healthy and unhealthy eating habits allows the development of actions that aim to improve the quality of life, as well as to help children's food and nutritional security.

\section{CONTRIBUTORS}

CS ANDREOLI was responsible for the conception, design, collection, analysis and interpretation of data, and for reviewing and endorsing the article. SA RIBEIRO-VIEIRA participated in the conception, design, collection, analysis and interpretation of data, revision and final approval of the article. PCA FONSECA was responsible for the collection, analysis and interpretation of data and for the final approval of the article. AVB MOREIRA and SMR RIBEIRO co-guided the project and participated in the review and final approval of the article. SCC FRANCESCHIN was the project coordinator and Research Advisor, participating in the design, data analysis and data interpretation, review and final approval of the article.

\section{ACKNOWLEDGMENTS}

Fundação de Amparo à Pesquisa do estado de Minas Gerais for granting research funding. 


\section{REFERENCES}

1. Rajindrajith S, Devanarayana NM, Crispus Perera BJ, Benninga MA. Childhood constipation as an emerging public health problem. World J Gastroenterol. 2016;22(30):6864-75. http://dx.doi. org/103748/wjg.v22i30.6864

2. Wu TC, Chen LK, Pan WH, Tang RB, Hwang SJ, Wu $\mathrm{L}$, et al. Constipation in Taiwan elementary school students: Nationwide survey. J Chin Med Assoc. 2011;74(2):57-61. http://dx.doi.org/10.1016/j.jcma. 2011.01.012

3. Vieira MC, Negrelle IC, Webber KU, Gosdal M, Truppel SK, Kusma SZ. Pediatrician's knowledge on the approach of functional constipation. Rev Paul Pediatr. 2016;34(4):425-31. http://dx.doi.org/10. 1016/j.rpped.2016.05.003

4. Ministério da Saúde (Brasil). Secretaria de Atenção à Saúde. Guia alimentar para a população brasileira. 2a ed. Brasília: Ministério da Saúde; 2014.

5. Barcelos GT, Rauber F, Vítolo MR. Produtos processados e ultraprocessados e ingestão de nutrientes em crianças. Rev Ciênc Saúde. 2014;7(3):155-61.

6. World Health Organization. Fruit and vegetable promotion initiative-report of meeting. Geneva: WHO; 2003 [cited 24 Feb. 2018]. Available from: http://www.who.int/iris/handle/10665/68395

7. Shau J, Chen PH, Chan CH, Hsu YC, Wu TC, James $F$, et al. Fast food: Are they a risk factor for functional gastrointestinal disorders? Asia Pac J Clin Nutr. 2016;25:393-401.

8. Asakura K, Masayasu S, Sasaki S. Dietary intake, physical, and time management are associated with constipation in preschool children in Japan. Asia Pac J Clin Nutr. 2017;26(1):118-29.

9. Mello CS, Freitas KC, Tahan S, Morais MB. Dietary fiber intake for children and adolescents with chronic constipation influence of mother or caretaker and relationship with overweight. Rev Paul Pediatr. 2010;2(2):188-93.

10. Lee WT, IP KS, Chan JS, Lui NW, Young BW. Increased prevalence of constipation in pre-school children is attributable to under-consumption of plant foods: A community-based study. J Paediatr Child Heath. 2008;44(4):170-5.

11. Kranz S, Brauchla M, Slavin JL, Miller KB. What do we know about dietary fiber intake in children and health? The effects of fiber intake on constipation, obesity, and diabetes in children. Adv Nutr. 2012;3(1):47-53.

12. Collins BR, O' Brien L. Prevention and management of constipation in adults. Nurs Stand. 2015;29(32):49-58.
13. Park M, Bang YG, Cho KY. Risk factors for functional constipation in young children attending daycare centers. J Korean Med Sc. 2016;31(8):1262-5.

14. Chan MF, Chan YL. Investigating factors associated with functional constipation of primary school children in Hong Kong. J Clin Nurs. 2010;19(23-24): 3390-400.

15. Chien LY, Liou YM, Chang P. Low defecation frequency in Taiwanese adolescents: Association with dietary intake, physical activity and sedentary behaviour. J Pediatr Child Health. 2011;47(6):381-6.

16. Vieira SA, Ribeiro AQ, Hermsdorff HHM, Priore SE, Franceschini SCC. Waist-to-height ratio index or the prediction of overweight in children. Rev Paul Pediatr. 2017;36:52-8. http://dx.doi.org/10. 1590/1984-0462/;2018;36;1;00002

17. Willet W, Stampfer MJ. Total energy intake: Implications for epidemiological analyses. Am J Epidemioly. 1986;124(1):17-27.

18. Monteiro CA, Cannon G, Levy RB, Moubarac JC, Jaime $P$, Martins AP, et al. NOVA: a estrela brilha (Classificação dos alimentos Saúde Pública). World Nutr. 2016;7(1-3):28-40.

19. Williams CL, Bollella M, Wynder El. A new recommendation for dietary fiber intake in childhood. Pediatrics. 1995;96(5Pt2):985-8.

20. Alves MN, Muniz LC, Vieira MF. Food intake among Brazilian children aged two to five years old: National Survey on Demography and Health (NSDH), 2006. Ciênc Saúde Coletiva. 2013;18(11):3369-77. http://dx.doi.org/10.1590/ S1413-81232013001100026

21. Hyams JS, Di Lorenzo C, Saps M, Shulman RJ, Staiano A, van Tiburg M. Functional disorders: Children and adolescents. Gastroenterology. 2016;S0016-5085(16)00181-5 http://dx.doi.org/10. 1053/j.gastro.2016.02.015

22. Lewis SJ, Heaton KW. Stool from scale as useful guide to intestinal transit time. Scand J Gastroenterol. 1997;32(9):920-4.

23. Saps M, Nichols-Vinueza D, Dhroove G, Adams $P$, Chogle A. Assessment of commonly used pediatric stool scales: A pilot study. Rev Gastroenterol Mex. 2013;78(3):151-8. http://dx.doi.org/10.1016/j.rgmx. 2013.04.001

24. Gomes RC, Maranhão HS, Pedrosa LFC, Morais $M B$. Fiber and nutrients intake in constipation children. Arq Gastroenterol. 2003;40(3):181-7. http://dx.doi.org/10.1590/S0004-280320030003 00009

25. Instituto Brasileiro de Geografia e Estatística. Pesquisa de orçamentos familiares 2008-2009: antropometria e estado nutricional de crianças, 
adolescentes e adultos no Brasil. Rio de Janeiro: IBGE;2010.

26. Sparrenberger K, Friedch RR, Schiffner MD, Schuch I, Wagner MB. Ultra-processed food consumption in children from a basic health unit. J Pediatr. 2015;91(6):535-42. http://dx.doi.org/10.1016/j.jped. 2015.01.007

27. Sujatha B, Velayutham DR, Deivamani $N$, Bavanandam S. Normal bowel pattern in children and dietary and other precipitating factors in functional constipation. J Clin Diagn Res. 2015;9(6):12-5. http://dx.doi.org/10.7860/jcdr/ 2015/13290.6025

28. Olaru C, Diaconescu S, Trandafir L, Gimiga N, Stefanescu G, Ciubotariu G, et al. Some risk factors of chronic functional constipation identified in pediatric population sample from Romania. Gastroenterol Res Pract. 2016;(2016):1-8. http:// dx.doi.org/10.1155/2016/3989721

29. Moraes JG, Motta MEFA, Beltrão MFS, Salviano TL, Silva GAP. Fecal microbiota and diet of children with chronic constipation. J Pediatr. 2016;2016:e6787269. http://dx.doi.org/10.115 5/2016/6787269

30. Boilesen SN, Tahan S, Dias FC, Melli LCFL, Morais $\mathrm{MB}$. Water and fluid intake in the prevention and treatment of functional constipation in children and adolescents: Is there evidence? J Pediatr. 2017;93(4):320-7. http://dx.doi.org/10.1016/j.jped. 2017.01.005

31. Jaime PC, Stopa SR, Oliveira TP, Vieira ML, Szwarcwald Cl, Malta DC. Prevalence and sociodemographic distribution of healthy eating markers, National Health Survey Brazil 2013. Epidemiol Serv Saúde. 2015;24(2):267-76. http:// dx.doi.org/10.5123/S1679-49742015000200009

32. Ruschel LF, Henn RL, Backes V, Melo P, Marques LAS, Olinto MTA. Food insecurity and inadequate food intake among students of municipal schools, São Leopoldo, state of Rio Grande do Sul, Brazil. Ciênc Saúde Coletiva. 2016;21(7)2275-85. http://dx.doi. org/10.1590/1413-81232015217.00742015

33. Lynch C, Kristjansdottir AG, Te Velde SJ, Lien N, Roos E, Thorsdottir I, et al. Fruit and vegetable consumption in sample of 11-year-old children in ten European countries the Pro Greens cross-sectional survey. Public Health Nutr. 2014;17(11):2436-44. http://dx.doi.org/10.1017/S 1368980014001347
Received: May 21, 2018

Final version: August 16, 2018 Approved: October 10, 2018 